\title{
Towards integrated cover crop management: N, P and S release from aboveground and belowground residues
}

\author{
Veronika Hansen $^{\mathrm{a}, *}$, Jørgen Eriksen ${ }^{\mathrm{b}}$, Lars Stoumann Jensen ${ }^{\mathrm{a}}$, Kristian Thorup-Kristensen ${ }^{\mathrm{a}}$, \\ Jakob Magid $^{\mathrm{a}}$
}

${ }^{a}$ Department of Plant and Environmental Sciences, University of Copenhagen, Thorvaldsensvej 40, 1871, Frederiksberg, Denmark

${ }^{\mathrm{b}}$ Department of Agroecology - Soil Fertility, Aarhus University, Blichers Allé 20, 8830, Tjele, Denmark

\section{A R T I C L E I N F O}

\section{Keywords:}

Cover crops

Nutrient uptake

Nutrient release

Low temperature

Aboveground residues

Belowground residues

\begin{abstract}
A B S T R A C T
Ecological intensification is crucial for arable organic farmers, in order to partly close the yield gap to conventional yields. One strategy for this is improved management of cover crops, to increase availability of both nitrogen (N), phosphorus (P) and sulfur (S) for the subsequent main crop. However, the potential of cover crops to take up and release nutrients has primarily been determined for aboveground biomass and mostly for N. There have been fewer studies on belowground biomass, and these have focused on recoverable roots. Thus, unrecoverable residues from rhizodeposits and nodules, have been overlooked. The aim of this incubation study was therefore to assess the release of $\mathrm{N}, \mathrm{P}$ and $\mathrm{S}$ from aboveground residues and from intact soil with belowground residues of different cover crop species at low temperature. Shoots and intact soil with roots from seven different cover crops were incubated for 80 days at a temperature of $5^{\circ} \mathrm{C}$.

A comparison of the cover crop species revealed a wide variation in nutrient uptake, chemical composition and release of N, P and S, that also varied between shoot and intact soil with roots. Release of N from shoots showed a marked non-stoichiometric behavior, in contrast to the release of $\mathrm{P}$ and $\mathrm{S}$, that correlated well with C:P and C:S ratios. $\mathrm{N}$ release (from Vicia villosa) and especially $\mathrm{P}$ mobilization (from legumes) in intact soil was much greater than the amounts determined in recoverable roots. This shows that unrecoverable pools such as rhizodeposits and fine roots contributed to nutrient release. Garden sorrel (Rumex acetosa) is a promising cover crop regarding uptake and mobilization of $\mathrm{P}$, but also as a multifunctional cover crop for supplying $\mathrm{N}, \mathrm{K}, \mathrm{S}$ and $\mathrm{Mg}$. Hairy vetch (Vicia villosa) is a promising cover crop for $\mathrm{N}$, oilseed radish (Raphanus sativus) for $\mathrm{S}, \mathrm{P}$ and $\mathrm{K}$, and white lupin (Lupinus albus) for N, P and Mn supply.

Based on our results, we propose the use of mixtures of cover crops with different N, P and S uptake and release having the potential to supply a more complete suite of nutrients to the subsequent crop.
\end{abstract}

\section{Introduction}

The demand for certified organic food products is growing in most affluent countries, which requires the area under organic agricultural production to be expanded. However, crop yields in organic farming are typically lower than from conventional farming, depending on the cropping system, soil fertility and site characteristics (Seufert et al., 2012). One of the reasons for this yield gap is lower nutrient availability in organic farming, especially N (Seufert et al., 2012; Shah et al. 2017). In the temperate, cooler and humid climates of northern Europe, cover crops have typically been grown in order to reduce nitrogen $(\mathrm{N})$ leaching losses from soil or as a green manure to increase $\mathrm{N}$ supply by biological $\mathrm{N}$ fixation (Thorup-Kristensen et al., 2003). Furthermore, organic farms without livestock have rather limited possibilities for $\mathrm{P}$ inputs, and in the long term this may cause substantial P limitations and yield loss (Cooper et al., 2018). Historically, little attention has been paid in many parts of the world to the S nutrition of plants due to atmospheric deposition of $S$ (Eriksen, 2009). This atmospheric input of $S$ has been significantly reduced by cleaning up $\mathrm{S}$ emissions from the consumption of fossil fuels. Consequently, crop S deficiency is more common and is typically corrected with fertilizers containing inorganic S, except in low-input and organic systems with limited access to mineral fertilizer. This may also be part of the explanation for the yield gap with conventional systems. This yield gap may be decreased through integrated cover crop

\footnotetext{
* Corresponding author.

E-mail address: veha@plen.ku.dk (V. Hansen).
} 
management. Integrated cover crop management can provide multiple ecosystem services that affect nutrient cycling, soil organic carbon storage, soil structure, water infiltration, erosion and soil biodiversity (De Baets et al., 2011; Sorensen and Thorup-Kristensen, 2011; Blanco-Canqui et al., 2015; Poeplau and Don, 2015). As a first step towards integrated cover crop management, there is a need to assess the effects of cover crop N, P and S mineralization and turnover in the soil.

Decomposition and $\mathrm{N}$ release or immobilization from incorporated cover crop shoot material have been extensively described (Magid et al., 2001; Jensen et al., 2005; Thomsen et al., 2016). In addition to N, cover crops can also release $\mathrm{P}$ and $\mathrm{S}$, and thus potentially contribute to $\mathrm{P}$ and $\mathrm{S}$ nutrition of the subsequent crop (Eriksen et al., 2004; Damon et al., 2014). Selecting species that can take up and release significant amounts of different nutrients would enable the development of multifunctional cover crop mixtures (Sorensen and Thorup-Kristensen, 2011). The release or immobilization of nutrients caused by the turnover of cover crop residues depends on the environmental conditions and residue quality, often represented by biochemical characteristics such as the concentration of $\mathrm{N}, \mathrm{P}$ and $\mathrm{S}$ in relation to the concentration of $\mathrm{C}$, and the concentration of lignin, cellulose and hemicellulose (Eriksen et al., 2004; Damon et al., 2014; Thomsen et al., 2016). However, it has also been argued that anatomical characteristics (e.g. spatial distribution of lignin) may be important for determining the entry of decomposers or the propensity of residues to leak soluble nutrient-rich materials into soils (Magid et al., 2004; Lindedam et al., 2009).

It has previously been assumed that $\mathrm{N}$ mineralization from incorporated cover crops is substantially delayed during periods with low temperatures, commonly observed in temperate climate agroecosystems (Magid et al., 2001), but several studies have indicated that when cover crops die off during winter, most of the first year $\mathrm{N}$ mineralization has already occurred before early spring (Muller and Sundman, 1988; Breland, 1994). Subsequently, Magid et al. (2001) observed for Medicago lupulina, Melilotus alba and Poa pratensis that while there was a strong temperature effect on the rate of $\mathrm{CO}_{2}$ evolution, and thus the extent of energy exhaustion from the added substrates, there was no concomitant retardation of $\mathrm{N}$ mineralization at low temperatures, which has also been confirmed by Andersen and Jensen (2001). In a further study, Magid et al. (2004) examined the turnover of various shoot materials. At the lowest temperature $\left(3^{\circ} \mathrm{C}\right)$, net immobilization of $\mathrm{N}$ was not observed, whereas at $9{ }^{\circ} \mathrm{C}$ net $\mathrm{N}$ immobilization was strong in some treatments. Their study demonstrated that while cell content leaked into the surrounding soil matrix from species with a low lignin content, high C-to-N cell walls mostly remained intact during low-temperature decomposition. It seems likely that such a dynamic would also be reflected in the release of $\mathrm{P}$ and $\mathrm{S}$ at low temperatures from such species.

The potential of cover crops to take up and release nutrients for subsequent crops has mostly been assessed for aboveground biomass, but less so for belowground biomass where the focus has mainly been on recoverable root materials (Eriksen et al., 2004; Liu et al., 2013; Thomsen et al., 2016; Li et al., 2020). Thus, the potential nutrient supply from belowground cover crop biomass may be underestimated since root debris, fragile and small roots, and nodules are difficult to separate from the soil (Fustec et al., 2009). Furthermore, cover crops can deposit significant amounts of $\mathrm{C}$ and $\mathrm{N}$ in the soil during growth in the form of rhizodeposits (Kanders et al., 2017). The contribution of N rhizodeposition by pea corresponded to between 7.5 and $17.8 \%$ of total plant $\mathrm{N}$, depending on the plant development stage (Arcand et al., 2013). Root exudates also influence $\mathrm{P}$ availability in soil either by solubilizing inorganic $\mathrm{P}$ via carboxylates and protons/hydroxyls or by hydrolyzing organic P via phosphatases (Hinsinger et al., 2011). Similarly, mineralization of $S$ also involves both biological and biochemical processes, and sulfate esters may be readily hydrolyzed by sulfatases, independent of the microbial need for C to provide energy (McGill and Cole, 1981; Eriksen, 2005). Furthermore, root nodules of legumes are rich in S due to the high content of $S$ in nitrogenase, the key enzyme of symbiotic nitrogen fixation (Becana et al., 2018). Thus, the $S$ mineralization from roots of legumes in the soil can be expected to be higher than predicted from recoverable roots, where full recovery of nodules may be very difficult to achieve.

Therefore, a greater understanding is required of the total contribution of the plant root system to the release and availability of N, P and $S$ for the succeeding crop. These pools can originate from: 1) release from recoverable roots, 2) fragile and small roots that are not possible to recover, 3) rhizodeposition and 4) changes in soil pools of plantavailable $\mathrm{N}, \mathrm{P}$ and $\mathrm{S}$ caused by root activity during cover crop growth. The term "intact soil with roots" was used in this study to include unrecoverable pools described above in point 2-4.

The aim of this study was therefore to assess the release of N, P and S from aboveground residues and from intact soil with belowground residues of different cover crop species at a low temperature.

Based on previous studies, the hypotheses were: (1) the release of $\mathrm{N}$, $\mathrm{P}$ and $\mathrm{S}$ in green shoot materials of cover crops at $5{ }^{\circ} \mathrm{C}$ will vary between species, (2) the intact soil harvested with roots will release more N, P and $\mathrm{S}$ compared with the recoverable root content, due to unrecoverable pools such as fine roots and rhizodeposition and (3) the nutrient release is related to $\mathrm{N}, \mathrm{P}$ and $\mathrm{S}$ concentrations and $\mathrm{C}: \mathrm{N}, \mathrm{C}: \mathrm{P}$ and $\mathrm{C}: \mathrm{S}$ ratio of cover crop residues.

\section{Materials and methods}

\subsection{Soil and plant material}

A sandy loam soil (14\% clay, $19 \%$ silt, $38 \%$ fine sand and $29 \%$ coarse sand) from a conventional agricultural field on the University of Copenhagen's research farm in Denmark was used. The soil contained $4.1 \%$ organic matter, $20 \mathrm{mg}$ Olsen- $\mathrm{P} \mathrm{kg}^{-1}, 168 \mathrm{mg} \mathrm{K} \mathrm{kg}{ }^{-1}$ and $53 \mathrm{mg}$ exchangeable $\mathrm{Mg} \mathrm{kg}^{-1}$, thus representing a soil of moderately low fertility. The soil $\mathrm{pH}_{\text {water }}$ was 6.5 and the total water-holding capacity (WHC) was $30 \%$. The two previous years, the field was cropped with oat and spring barley in 2017 and 2018, respectively. During the period from cover crop sowing to biomass sampling, the mean temperature was $13{ }^{\circ} \mathrm{C}$ and accumulated precipitation was $120 \mathrm{~mm}$.

Seven different cover crops species were sown on 16 August 2018: buckwheat (Fagopyrum esculentum), crimson clover (Trifolium incarnatum), Italian ryegrass (Lolium multiflorum), oilseed radish (Raphanus sativus), garden sorrel (Rumex acetosa), white lupin (Lupinus albus) and hairy vetch (Vicia villosa). Each cover crop species was sown in one $1 \mathrm{~m} \times$ $12 \mathrm{~m}$ plot in $12 \mathrm{~cm}$ wide rows. One extra plot without any cover crops was established as a control fallow plot, where weeds were removed by hand three times. Shoots were harvested on 1 November 2018 by cutting the plants at the soil surface from $0.5 \mathrm{~m}$ long row at 10 different places in the plot and combined to obtain one composite sample per plot. However, the shoots of oilseed radish were harvested differently, i.e. a few $\mathrm{cm}$ above the ground just between the shoots and taproot. The part of the taproot growing aboveground was considered as part of the belowground biomass. All weeds were removed from the composite sample after cutting. All the species were in the vegetative growth stage, apart from buckwheat that was at the flowering stage. For the incubation of shoot biomass, the control soil was sampled from the control plot by a spade to $10 \mathrm{~cm}$ depth from two $0.5 \mathrm{~m}^{2}$ areas of the weeded plot. All weeds were also removed by hand from two $0.25 \mathrm{~m}^{2}$ spots in each cover crop plot to secure the maximum plant and root growth of the intended species. For the incubation of roots, intact soil with roots from each species was excavated by a spade to $10 \mathrm{~cm}$ depth from two $50 \mathrm{~cm}$ long and $12 \mathrm{~cm}$ wide rows of the weeded spot in order to give the real soil-toroot ratio from the field and to include dead roots, root hairs, rhizodeposits etc. The taproot of oilseed radish was subsequently cut by scissors at the right depth. Shoots, intact soil with roots and control soil for the incubation were stored at $5{ }^{\circ} \mathrm{C}$ until incubation was set up the following day. The water content of shoots and soil was determined.

For biomass dry matter determination and nutritional analyses, 
shoot samples were taken by cutting the plants at the soil surface in two $0.25 \mathrm{~m}^{2}$ subplots. Roots were recovered by excavating the soil with roots to a $0-10 \mathrm{~cm}$ depth using a spade. Subsequently, the roots were gently washed under running water to remove all soil. Both shoot and recoverable root samples were dried in an oven for $48 \mathrm{~h}$ at $45^{\circ} \mathrm{C}$ to determine biomass dry matter. Prior to measuring the macro and micronutrient content, the shoots and roots were milled to a fine powder. The $\mathrm{C}$ and $\mathrm{N}$ content of shoot and root samples were analyzed using an elemental CNS analyzer (CNS Vario Macro cube, Elementar). For analysis of B, Ca, K, $\mathrm{Mg}, \mathrm{Mn}, \mathrm{Mo}, \mathrm{P}, \mathrm{S}$ and $\mathrm{Zn}$ content, milled shoot and root samples were digested with $\mathrm{HNO}_{3}$ and $\mathrm{H}_{2} \mathrm{O}_{2}$ in a microwave oven and analyzed using an ICP-OES (Agilent 5100). Fiber (lignin, cellulose and hemicellulose) in shoots and roots was analyzed using the method of Van Soest et al. (1991).

\subsection{Incubation setup}

For incubation with shoots, fresh plant material was chopped into approximately $10 \mathrm{~mm}$ long pieces. In $120-\mathrm{mL}$ PVC containers, fresh control soil corresponding to $75 \mathrm{~g}$ DM was mixed thoroughly with fresh shoot material corresponding to $0.75 \mathrm{~g} \mathrm{DM}(1 \%)$. For the incubation of orthophosphate $\mathrm{P}$ was measured the following day using a flow injection analyzer. The content of total inorganic sulfate was analyzed by extracting $20 \mathrm{~g}$ fresh soil with $40 \mathrm{~mL} \mathrm{KH}_{2} \mathrm{PO}_{4}\left(500 \mathrm{mg} \mathrm{l}^{-1}\right)$, which was then shaken for $1 \mathrm{~h}$, centrifuged and filtered. Organic matter was removed by adding activated charcoal to the extract and the sulfate content was determined turbidimetrically after acidification with hydrochloric acid (Eriksen, 2005). Soil pH was measured on air-dried soil using a soil-water suspension of $5 \mathrm{~g}$ soil (DM) and $25 \mathrm{~mL}$ of Milli-Q water ( $\mathrm{pH}$ meter Mettler-Toledo AG, Switzerland).

\subsection{Calculations and statistical analysis}

The N, P and S mineralization/mobilization from cover crops was calculated by subtracting the content of mineral $\mathrm{N}$ (Nmin), extractable $\mathrm{P}$ and $S$ in the control soil from the amended soil treatment on all sampling days. The proportion of mineralization/mobilization of N, P and S in intact soil with roots was estimated based on the N, P and S in recoverable roots and indicated as the percentage of estimated root N, P and $S$ throughout this study and was calculated as follows (same calculation was used for P and S):2

$\%$ of estimated root $N$ mineralized $=\frac{\mathrm{Nmin} \text { in intact soil with roots }-\mathrm{Nmin} \text { in control treatment }}{\mathrm{N} \text { in recoverable roots }} \times 100$

intact soil with roots, the fresh roots were cut into approximately $10 \mathrm{~mm}$ long pieces in the soil. The taproots of oilseed radish were cut with a knife to $10 \mathrm{~mm}$ pieces. After thorough mixing, fresh soil with roots corresponding to $75 \mathrm{~g}$ DM was placed in the plastic containers. The
Estimated release potential of $\mathrm{N}$ from shoots $\left(\mathrm{kg} \mathrm{N}^{-1}\right)$ was based on the $\mathrm{N}$ mineralization data from the incubation experiment and calculated as follows (same calculation was used for P and S):

Estimated release potential $=\frac{\mathrm{N} \text { uptake in shoots } \times \% \text { of added shoot } \mathrm{N} \text { mineralized }}{100}$

containers were arranged in completely randomized design with four replicates for incubation with shoots and six replicates for incubation of intact soil with roots. All containers were packed to reach a bulk density of $1.5 \mathrm{~g} \mathrm{~cm}^{-3}$ by gently pressing the soil in the containers. All containers were watered to $60 \%$ of total WHC and moisture was kept constant by weighing and watering once a week. The containers were incubated uncovered at a constant temperature of $5{ }^{\circ} \mathrm{C}$ in the dark for 80 days.

\subsection{Soil analysis}

The whole experiment was set up in five sets allowing destructive soil samplings at day 1, 7, 20, 40 and 80 of the incubation for both incubation with shoots and intact soil with roots. All treatments were analyzed for mineral $\mathrm{N}$, water-extractable $\mathrm{P}$, sulfate and $\mathrm{pH}$. The content of mineral $\mathrm{N}\left(\mathrm{NO}_{3}^{-}+\mathrm{NH}_{4}^{+}\right)$was measured by extracting $10 \mathrm{~g}$ fresh soil with $40 \mathrm{~mL} 1 \mathrm{M} \mathrm{KCl}$, which was then shaken for $1 \mathrm{~h}$ on a turn-over shaker and filtered through a $2.5 \mu \mathrm{m}$ filter (Whatman no.5). The extracts were frozen until analyzes of $\mathrm{NO}_{3}^{-}+\mathrm{NH}_{4}^{+}$were undertaken using a flow injection analyzer (FIA star 5000, Foss Analytical, Denmark). Waterextractable P (WEP) was used as a proxy for easily available P (Lemming et al. 2017; van der Paauw, 1971). The content of WEP was analyzed by extracting $0.75 \mathrm{~g}$ fresh soil with Milli-Q water $(\mathrm{ml})$ at a soil water ratio of 1:60 (g:ml), which was shaken for $1 \mathrm{~h}$, centrifuged and filtered through the same filter as for mineral $\mathrm{N}$. The filtered extracts were stored at $4{ }^{\circ} \mathrm{C}$ until the content of water-extractable
All statistical analyses were performed using $\mathrm{R}$ version 3.4.2 ( $\mathrm{R}$ Core Team, 2017) and the RStudio development environment (RStudio Team, 2017). Statistical differences were tested by one-way ANOVA. The differences between cover crops species were analyzed using least-square means from the R-package lsmeans. The soil $\mathrm{pH}$ was analyzed using the subset function to find significant differences between cover crop species within each sampling day and between sampling days within each cover crop species. All statistical models were checked for normality of residuals and homogeneity of variance using diagnostic plots. All differences at $p<0.05$ were reported as significant.

\section{Results}

\subsection{Plant biomass}

The total biomass production of cover crops in the field varied between $1518 \mathrm{~kg} \mathrm{DM} \mathrm{ha}^{-1}$ (vetch) and $4227 \mathrm{~kg} \mathrm{DM} \mathrm{ha}^{-1}$ (buckwheat) (Table 1). Nutrient uptake varied between species and plant residues part (shoots vs. roots). During the 77 days of the autumn growth period, lupin attained the highest uptake of $\mathrm{N}$, whereas sorrel and oilseed radish achieved the highest uptake of $\mathrm{P}$ in shoots and roots combined. For S, oilseed radish had by far the highest total uptake of $15.6 \mathrm{~kg} \mathrm{~S}^{-1}$, which was more than twice the $S$ uptake by any other cover crop 
Table 1

Biomass production in shoots and roots (excavated from $10 \mathrm{~cm}$ depth) and uptake of $\mathrm{N}, \mathrm{P}$ and $\mathrm{S}$ in shoots and roots.

\begin{tabular}{|c|c|c|c|c|c|c|c|c|c|}
\hline & \multicolumn{3}{|c|}{ Biomass (kg DM ha ${ }^{-1}$ ) } & \multicolumn{3}{|c|}{ Uptake in shoots $\left(\mathrm{kg} \mathrm{ha}^{-1}\right)$} & \multicolumn{3}{|c|}{ Uptake in roots $\left(\mathrm{kg} \mathrm{ha}^{-1}\right)$} \\
\hline & Shoots & Roots & Total & $\mathrm{N}$ & $\mathrm{P}$ & $S$ & $\mathrm{~N}$ & $\mathrm{P}$ & $S$ \\
\hline Buckwheat & 3854 & 373 & 4227 & 67.8 & 12.6 & 5.2 & 3.5 & 1.0 & 0.4 \\
\hline Clover & 2088 & 296 & 2384 & 92.5 & 7.6 & 5.2 & 8.1 & 1.3 & 1.0 \\
\hline Lupin & 2842 & 416 & 3258 & 122.5 & 10.1 & 6.5 & 11.7 & 1.4 & 1.2 \\
\hline Oilseed radish & 2035 & 1053 & 3088 & 64.7 & 13.2 & 8.4 & 18.6 & 7.9 & 7.2 \\
\hline Ryegrass & 2456 & 862 & 3318 & 71.2 & 9.4 & 5.9 & 9.6 & 2.3 & 1.1 \\
\hline Sorrel & 1838 & 898 & 2736 & 62.5 & 15.2 & 4.9 & 12.0 & 5.7 & 1.2 \\
\hline Vetch & 1376 & 142 & 1518 & 62.2 & 6.0 & 3.8 & 5.2 & 0.6 & 0.8 \\
\hline
\end{tabular}

Table 2

Nutrient composition, C:N, C:P and C:S ratios, and the content of lignin, cellulose and hemicellulose of cover crop shoot and root biomass.

\begin{tabular}{|c|c|c|c|c|c|c|c|c|c|c|c|c|c|c|c|c|c|}
\hline Species & $\begin{array}{l}\text { B } \\
\mu g^{-1}\end{array}$ & Mn & Mo & $\mathrm{Zn}$ & $\begin{array}{l}\mathrm{Ca} \\
\mathrm{mg} \mathrm{g}^{-1}\end{array}$ & $\mathrm{~K}$ & $\mathrm{Mg}$ & $\mathrm{P}$ & $S$ & $\begin{array}{l}\mathrm{N} \\
\%\end{array}$ & $\mathrm{C}$ & C:N & $\mathrm{C}: \mathrm{P}$ & C:S & $\begin{array}{l}\text { Lignin } \\
\%\end{array}$ & Cellulose & Hemicellulose \\
\hline \multicolumn{18}{|l|}{ Shoot material } \\
\hline Buckwheat & 18.8 & 33.5 & 0.9 & 31.9 & 13.9 & 19.3 & 2.0 & 3.3 & 1.4 & 1.8 & 43.3 & 25 & 132 & 319 & 4.2 & 19.3 & 17.1 \\
\hline Clover & 31.9 & 23.3 & 1.4 & 32.2 & 12.8 & 30.3 & 1.5 & 3.6 & 2.5 & 4.4 & 45.4 & 10 & 125 & 181 & 1.1 & 16.7 & 11.6 \\
\hline Lupin & 22.8 & 535.8 & 1.3 & 34.7 & 10.8 & 34.5 & 1.5 & 3.6 & 2.3 & 4.3 & 44.9 & 10 & 126 & 195 & 1.5 & 25.4 & 5.5 \\
\hline Oilseed radish & 33.8 & 25.6 & 1.5 & 29.4 & 11.0 & 52.8 & 1.3 & 6.5 & 4.1 & 3.2 & 41.1 & 13 & 64 & 100 & 0.6 & 18.8 & 0.0 \\
\hline Ryegrass & 2.3 & 31.2 & 1.7 & 22.2 & 5.0 & 34.1 & 0.9 & 3.8 & 2.4 & 2.9 & 43.5 & 15 & 114 & 180 & 0.7 & 19.0 & 16.0 \\
\hline Sorrel & 19.4 & 47.7 & 1.4 & 31.2 & 4.4 & 51.1 & 2.5 & 8.2 & 2.7 & 3.4 & 41.9 & 12 & 51 & 156 & 1.4 & 12.6 & 8.3 \\
\hline Vetch & 41.8 & 32.8 & 1.6 & 55.0 & 16.8 & 31.1 & 1.9 & 4.4 & 2.7 & 4.5 & 41.6 & 9 & 95 & 152 & 2.5 & 18.4 & 6.6 \\
\hline \multicolumn{18}{|c|}{ Recovered root material } \\
\hline Buckwheat & 11.7 & 43.1 & 1.2 & 28.3 & 9.0 & 19.7 & 1.5 & 2.6 & 0.9 & 0.9 & 42.5 & 46 & 162 & 447 & 11.3 & 38.8 & 10.5 \\
\hline Clover & 26.6 & 28.4 & 3.2 & 38.6 & 4.9 & 30.5 & 1.7 & 4.5 & 3.5 & 2.7 & 42.6 & 16 & 95 & 123 & 2.6 & 33.6 & 10.5 \\
\hline Lupin & 12.5 & 65.2 & 5.2 & 37.3 & 3.1 & 27.5 & 1.1 & 3.3 & 2.9 & 2.8 & 43.7 & 16 & 134 & 153 & 6.0 & 40.0 & 11.8 \\
\hline Oilseed radish & 21.7 & 11.1 & 1.6 & 35.6 & 5.3 & 40.7 & 1.2 & 7.5 & 6.8 & 1.8 & 40.0 & 23 & 53 & 58 & 3.0 & 16.7 & 2.0 \\
\hline Ryegrass & 3.7 & 54.3 & 0.8 & 60.9 & 3.9 & 18.3 & 1.0 & 2.6 & 1.3 & 1.1 & 41.3 & 37 & 157 & 315 & 3.6 & 30.7 & 26.0 \\
\hline Sorrel & 23.4 & 26.0 & 0.5 & 29.6 & 5.6 & 23.9 & 3.9 & 6.3 & 1.3 & 1.3 & 42.9 & 32 & 68 & 319 & 1.7 & 12.1 & 6.5 \\
\hline Vetch & 17.3 & 34.3 & 5.1 & 62.8 & 5.3 & 38.5 & 3.2 & 4.0 & 5.9 & 3.6 & 41.3 & 11 & 104 & 70 & 5.1 & 23.9 & 7.3 \\
\hline
\end{tabular}

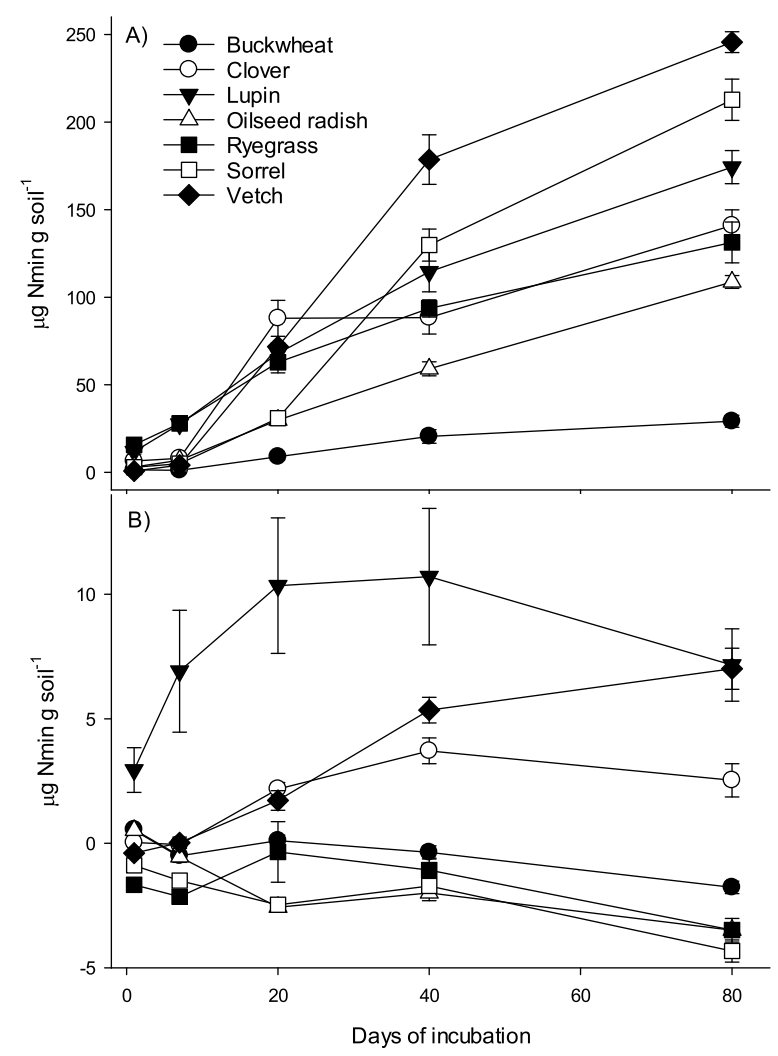

Fig. 1. Content of mineral nitrogen $\left(\mathrm{N}_{\min }\right)$ in cover crop treatments minus control soil, extracted on days 1, 7, 20, 40 and 80 of the incubation period: A) in soil with shoots, B) in intact soil with roots. Values presented here are means with standard error bars ( $n=4$ for shoots and $n=6$ for roots).
(Table1). A comparison of the nutrient composition of the plant biomass showed wide variations between cover crop species and to a lesser extent between the plant residue parts (Table 2). The legumes (clover, lupin and vetch) had the highest $\mathrm{N}$ concentration in both shoots and roots. Sorrel and oilseed radish had the highest concentration of $\mathrm{P}$ in shoots and roots, while sorrel had the highest $\mathrm{Mg}$ concentration in both shoots and roots. Oilseed radish had the highest $\mathrm{S}$ and $\mathrm{K}$ concentrations in both shoots and roots. The shoots of vetch had the highest concentrations of $\mathrm{B}, \mathrm{Ca}$ and $\mathrm{Zn}$, whereas the shoots and roots of lupin had the highest concentration of $\mathrm{Mn}$. The shoots were generally low in lignin content (0.6-2.5\%) except for buckwheat, which was slightly higher (4.2\%). The shoots and roots of buckwheat had the highest C:N, C:P and $\mathrm{C}: \mathrm{S}$ ratios. In all species, the $\mathrm{N}$ concentration was higher and the content of lignin lower in shoots than in roots. Consequently, the shoot biomass of all species had a lower C:N ratio than the root biomass, whereas the C: $\mathrm{P}$ and $\mathrm{C}: \mathrm{S}$ ratios showed a more diverse pattern. There was a significant correlation between shoots and roots in $\mathrm{N}$ concentration $\left(\mathrm{R}^{2}=0.81, p=\right.$ $0.0059), \mathrm{C}: \mathrm{N}$ ratio $\left(\mathrm{R}^{2}=0.78, p=0.008\right)$ and lignin content $\left(\mathrm{R}^{2}=0.78\right.$, $p=0.0081$ ) (data not shown).

\subsection{Soil nutrient availability}

\subsubsection{Nitrogen mineralization}

The highest amount of mineral $\mathrm{N}$ released from shoots after 80 days of incubation was from vetch, sorrel and lupin, and the lowest was from buckwheat (Fig. 1A, Table 3). Sorrel released $63 \%$, whereas buckwheat released only $17 \%$ of its $\mathrm{N}$ content (Table 3 ). The $\mathrm{N}$ release from shoots was not significantly related to the $\mathrm{C}: \mathrm{N}$ ratio or to the $\mathrm{N}$ concentration of the shoot biomass (Fig. 2A, B), and the prediction was not improved by including the content of lignin, cellulose and hemicellulose (data not shown). Incubation of intact soil with lupin, vetch and clover roots resulted in a net $\mathrm{N}$ mineralization, whereas intact soil with non-legume roots led to a net $\mathrm{N}$ immobilization (Fig. 1B). The intact soil with lupin roots started with rapid mineralization during the first 40 days of 
Table 3

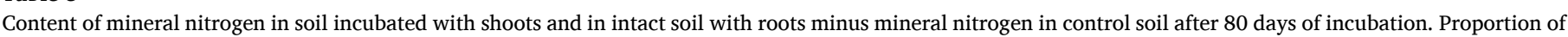

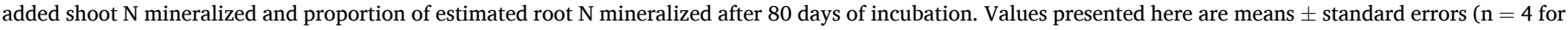
shoots, $\mathrm{n}=6$ for roots). Lower case letters indicate statistical differences between cover crop species (p $<0.05$ ).

\begin{tabular}{|c|c|c|c|c|}
\hline & \multicolumn{2}{|c|}{ Mineral nitrogen $\mu \mathrm{g}_{\mathrm{g} \text { soil }}{ }^{-1}$} & \multirow{2}{*}{$\%$ of added shoot $\mathrm{N}$ mineralized } & \multirow{2}{*}{$\%$ of estimated root $\mathrm{N}$ mineralized } \\
\hline & Shoots & Intact soil with roots & & \\
\hline Buckwheat & $29 \pm 3.4 \mathrm{e}$ & $-1.8 \pm 0.2 c$ & $17 \pm 1.9 \mathrm{e}$ & $-48 \pm 6.8 c$ \\
\hline Clover & $141 \pm 8.9 \mathrm{~cd}$ & $2.5 \pm 0.7 \mathrm{~b}$ & $32 \pm 2.0 \mathrm{~d}$ & $30 \pm 12.3 b$ \\
\hline Lupin & $174 \pm 9.5 \mathrm{bc}$ & $7.2 \pm 1.5 \mathrm{a}$ & $40 \pm 2.2 \mathrm{~cd}$ & $57 \pm 16.8 b$ \\
\hline Oilseed radish & $109 \pm 3.7 \mathrm{~d}$ & $-3.5 \pm 0.5 c$ & $34 \pm 1.1 \mathrm{~cd}$ & $-18 \pm 2.5 c$ \\
\hline Ryegrass & $131 \pm 11.7 \mathrm{~cd}$ & $-3.5 \pm 0.3 c$ & $45 \pm 4.0 \mathrm{bc}$ & $-34 \pm 2.4 c$ \\
\hline Sorrel & $213 \pm 11.8 \mathrm{ab}$ & $-4.3 \pm 0.4 c$ & $63 \pm 3.5 \mathrm{a}$ & $-34 \pm 5.0 \mathrm{c}$ \\
\hline Vetch & $246 \pm 5.9 \mathrm{a}$ & $7.0 \pm 0.8 \mathrm{a}$ & $54 \pm 1.3 \mathrm{ab}$ & $128 \pm 23.7$ a \\
\hline
\end{tabular}

incubation, while the vetch treatment showed a more constant mineralization reaching the same net mineralization as lupin after 80 days. The intact soil with clover and lupin roots released 30 and $57 \%$ of $\mathrm{N}$ in recoverable roots respectively, while the vetch treatment released $128 \%$ (Table 3). Mineralization in intact soil was significantly related to the C: $\mathrm{N}$ ratio of the root material (Fig. 2D), but the correlation with $\mathrm{N}$ concentration was even stronger (Fig. 2C).

\subsubsection{Phosphorus mobilization}

Incubation of shoots and intact soil with roots of all species resulted in a net WEP release, except for intact soil with oilseed radish roots, at day 4 (Fig. 3). A high degree of mobilization of $\mathrm{P}$ in the WEP pool resulted from the turnover of shoot material of sorrel (50\% of shoot content) and oilseed radish ( $31 \%$ of shoot content) at the end of the incubation. Lupin, clover and buckwheat mobilized the lowest amount of WEP (8-11 \% of shoot content) (Fig. 3A, Table 4). The P mobilization by shoots was significantly related to the C:P ratio (Fig. 4B), but the correlation between $\mathrm{P}$ mobilization and total $\mathrm{P}$ concentration was slightly stronger (Fig. 4A). The intact soil with sorrel roots also resulted in the highest mobilization, whereas soil with buckwheat roots resulted in the lowest mobilization (Fig. 3B). However, the relative mobilization of $\mathrm{P}$ was highest for the legumes (188-321 \% of estimated root $\mathrm{P}$ ) and lowest for oilseed radish (30\%) (Table 4). The P mobilization in soil with roots was not correlated with the C:P ratio or with the P concentration of the root biomass (Fig. 4C, D), and the prediction was not improved by including the content of lignin, cellulose and hemicellulose (data not shown).

\subsubsection{Sulfur mineralization}

Shoots from oilseed radish showed the highest release of sulfate followed by sorrel, whereas buckwheat did not release any S (Fig. 5A). Sorrel shoots released the highest fraction of the added shoot S (34\%), while oilseed radish released $28 \%$ (Table 5). Incubation of intact soil with roots generally resulted in low $\mathrm{S}$ mineralization, with less than $4 \%$ of estimated root $S$ being mineralized. Intact soil with lupin roots started with rapid mineralization during the first 20 days of incubation, but reached the same level as the other legumes after 80 days. Incubation of intact soil with ryegrass and buckwheat roots caused immobilization throughout the incubation period, whereas soil with clover roots led to immobilization until day 40 of the incubation (Fig. 5B). The S mineralization from shoots and intact soil with roots was most significantly correlated with the C:S ratio of incubated material (Fig. 6B, D).

\subsubsection{Estimated nutrient release potential in the field}

Using release rate data from the incubation study, the potential for nutrient release in the experimental field from shoots and intact soil with roots was estimated (Table 6). Eighty days after incorporation, lupin would release the highest amount of $\mathrm{N}\left(56 \mathrm{~kg}_{\text {mineral }} \mathrm{N} \mathrm{ha}^{-1}\right)$, followed by vetch $\left(40 \mathrm{~kg}\right.$ mineral $\mathrm{N} \mathrm{ha}^{-1}$ ), whereas buckwheat would release only $10 \mathrm{~kg}$ mineral $\mathrm{N} \mathrm{ha}^{-1}$. Sorrel would release the highest amount of orthophosphate-P $\left(12 \mathrm{~kg} \mathrm{P} \mathrm{ha}^{-1}\right)$, with lupin, ryegrass and oilseed radish potentially contributing 4-6 kg orthophosphate- $\mathrm{P} \mathrm{ha}^{-1}$. Oilseed radish would release the highest amount of sulfate $\left(3 \mathrm{~kg} \mathrm{~S} \mathrm{ha}^{-1}\right)$.

\subsubsection{Soil $p H$}

The incubation of shoots and intact soil with roots resulted in

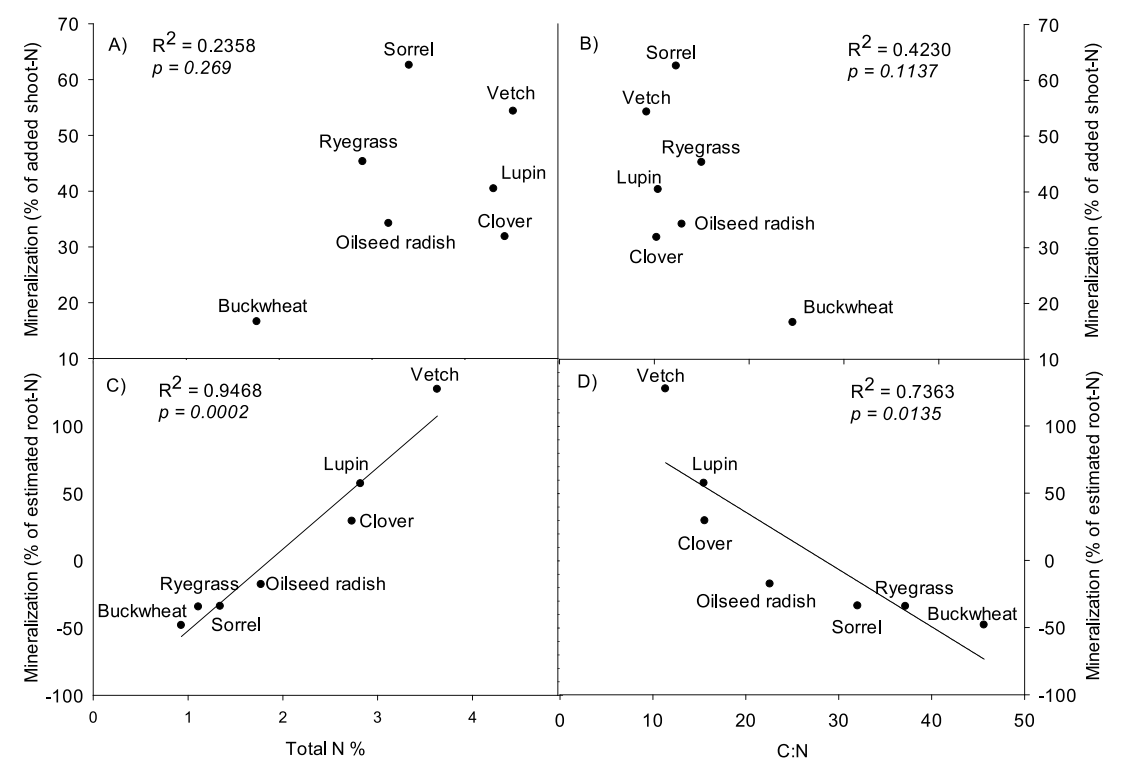

Fig. 2. Proportion of mineralized $N$ from added cover crop $N$ after 80 days of incubation as a function of total $N \%$ (A, C) and C:N ratio (B, D) in soil with shoots (A, B) and intact soil with roots (C, D). 


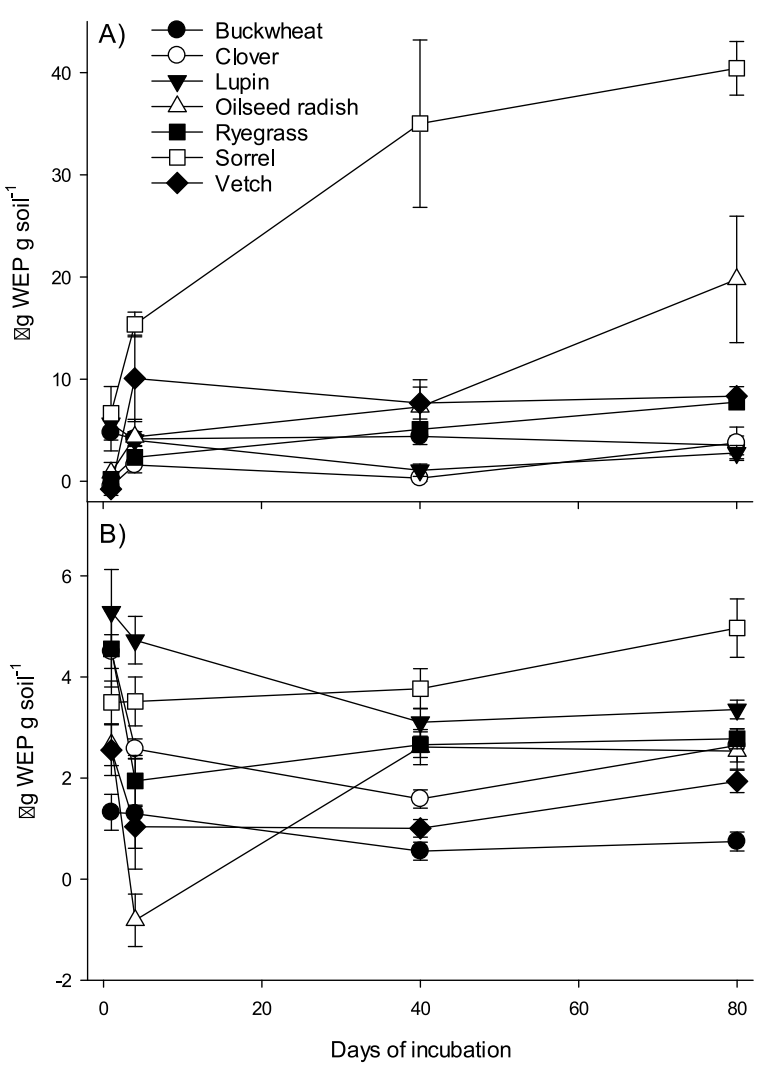

Fig. 3. Content of water-extractable phosphorus (WEP) in cover crop treatments minus control soil, during 80 days of incubation measured in A) soil with shoots and B) intact soil with roots. Values presented here are means with standard error bars ( $n=4$ for shoots, $n=6$ for roots).

increased or decreased soil $\mathrm{pH}$, depending on the species and time of sampling (Table 7). Soil pH in the control soil was stable (at 6.5) during the incubation, while $\mathrm{pH}$ in soil incubated with shoots increased (0.1-0.4 units) in most treatments after 20 days and subsequently decreased (0.5-1.1 units) by day 80 . The exception was buckwheat, which showed a decreased $\mathrm{pH}(0.25$ units) after day 20 and subsequently reverted to $\mathrm{pH} 6.48$ at day 80 . In the intact soil with roots, $\mathrm{pH}$ generally increased by $0.1-0.3$ units throughout the incubation, except for vetch where it remained unchanged.

\section{Discussion}

\subsection{Release of $N, P$ and $S$ from cover crop shoot residues}

In the present study, release of N, P and S from shoot residues varied substantially between cover crop species. Most of the species had a low $\mathrm{C}: \mathrm{N}$ ratio, ranging from 9 to 15 , and a low lignin content $(<3 \%)$ apart from buckwheat, which had a C:N ratio of 25 and a lignin content of 4.2 $\%$. It is interesting that none of the aforementioned biochemical characteristics were significantly correlated with $\mathrm{N}$ release, which was markedly non-stoichiometric. Vetch, sorrel and lupin released the highest amounts of $\mathrm{N}$ from shoot residue, whereas buckwheat released the lowest amount. In Fig. 2B, it is notable that while all residues excluding buckwheat fell within a narrow $\mathrm{C}: \mathrm{N}$ ratio range (9-15), their mineralization varied considerably from 35 to $65 \%$ of added $\mathrm{N}$. Ryegrass had the highest C:N (15), resulting in an average mineralization (45\%), while clover had a much lower C:N (10) but resulted in a lower mineralization ( $32 \%$ ). In this experiment, we chose an incubation temperature of $5{ }^{\circ} \mathrm{C}$ to reflect low soil temperatures in Danish soil during winter. This does not accurately reflect the conditions in the field with fluctuating temperatures, but it is a better choice than the much higher temperatures that are often used. Magid et al. (2001) noted disproportionately high $\mathrm{N}$-mineralization rates from green manures at low temperatures, compared to higher temperatures. In a further study, Magid et al. (2004) demonstrated that incubation at low temperature altered the mineralization dynamics by decreasing the turnover of energy-rich cell wall tissues in favor of more soluble intra-cellular components. Lindedam et al. (2009) discussed tissue architecture and its control on the decomposition of roots. They presented strong evidence to indicate that the arrangement of tissues and thus barriers for entry of the decomposer population is a significant determinant of decomposition. In a similar vein, the decomposition of the shoot materials in the present study at a low temperature where carbon turnover was temperature limited may be affected by differences in the release of low molecular substances to soil due to differences in tissue structures.

The P mobilization was correlated with total P concentration and C:P ratio, as has also been shown in other studies (Liu et al., 2013; Hallama et al., 2019). We used the water extractable $\mathrm{P}$ - method, which has been recently shown to be highly sensitive in measuring changes of easily soluble P during incubation trials (Lemming et al. 2017). It extracts the soil in a high liquid to solid ratio of 60 , allowing the water to act as a strong sink for $\mathrm{P}$, but extracting less $\mathrm{P}$ than more powerful extractants (e. g. Olsen P), and it is not a complicated method. It does by no means uncover the full picture of the soil $\mathrm{P}$ dynamics, involving resorption and the specific contribution from organic pools, that may be better elucidated by the use of isotopic exchange kinetics and isotope dilution experiments employing ${ }^{33} \mathrm{P}$.

In the case of $\mathrm{P}$, sorrel followed by oilseed radish released the highest amounts, which is in line with Sorensen and Thorup-Kristensen (2011) and Liu et al. (2013). Sorrel is less known as a cover crop, but has been identified as cover crop with deep roots and promising P effects and suitable to be undersown into a main crop in the spring (Sorensen and Thorup-Kristensen, 2011; Thorup-Kristensen and Rasmussen, 2015). No marked changes in soil $\mathrm{pH}$ were observed during incubation (Table 7) that could explain differences in the mobilization of $P$ in the WEP pool. It should be noted that while changes in the WEP pool are good indicators of changes in plant-available $\mathrm{P}$, they do not fully capture the release from the plant material. Some of the $\mathrm{P}$ released from plants may have

Table 4

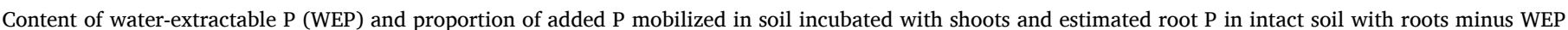

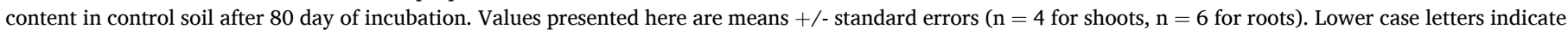
statistical differences between cover crop species $(\mathrm{p}<0.05)$.

\begin{tabular}{|c|c|c|c|c|}
\hline & \multicolumn{2}{|c|}{ Water-extractable $\mathrm{P} \mu \mathrm{g} g$ soil $^{-1}$} & \multirow[t]{2}{*}{$\%$ of added shoot $\mathrm{P}$ mobilized } & \multirow[t]{2}{*}{$\%$ of estimated root $\mathrm{P}$ mobilized } \\
\hline & Shoots & Intact soil with roots & & \\
\hline Buckwheat & $3.5 \pm 0.9 \mathrm{c}$ & $0.8 \pm 0.2 \mathrm{~cd}$ & $11 \pm 2.8 \mathrm{bc}$ & $72 \pm 18.1 \mathrm{de}$ \\
\hline Clover & $3.7 \pm 1.6 \mathrm{c}$ & $2.7 \pm 0.3 \mathrm{~b}$ & $10 \pm 4.3 \mathrm{bc}$ & $188 \pm 23.2 \mathrm{bc}$ \\
\hline Lupin & $2.8 \pm 0.7 \mathrm{c}$ & $3.4 \pm 0.2 \mathrm{~b}$ & $8 \pm 2 c$ & $233 \pm 12.9 \mathrm{~b}$ \\
\hline Oilseed radish & $19.8 \pm 6.2 b$ & $2.5 \pm 0.4 \mathrm{~b}$ & $31 \pm 9.6 \mathrm{ab}$ & $30 \pm 4.2 \mathrm{e}$ \\
\hline Ryegrass & $7.8 \pm 0.5 \mathrm{c}$ & $2.8 \pm 0.2 \mathrm{~b}$ & $20 \pm 1.3 \mathrm{bc}$ & $115 \pm 8.2 \mathrm{~cd}$ \\
\hline Sorrel & $40.4 \pm 2.6 \mathrm{a}$ & $4.9 \pm 0.6 \mathrm{a}$ & $50 \pm 3.2 \mathrm{a}$ & $82 \pm 9.5 \mathrm{de}$ \\
\hline Vetch & $8.3 \pm 0.9 b c$ & $1.9 \pm 0.2 \mathrm{bc}$ & $19 \pm 2.1 \mathrm{bc}$ & $321 \pm 36.9 \mathrm{a}$ \\
\hline
\end{tabular}




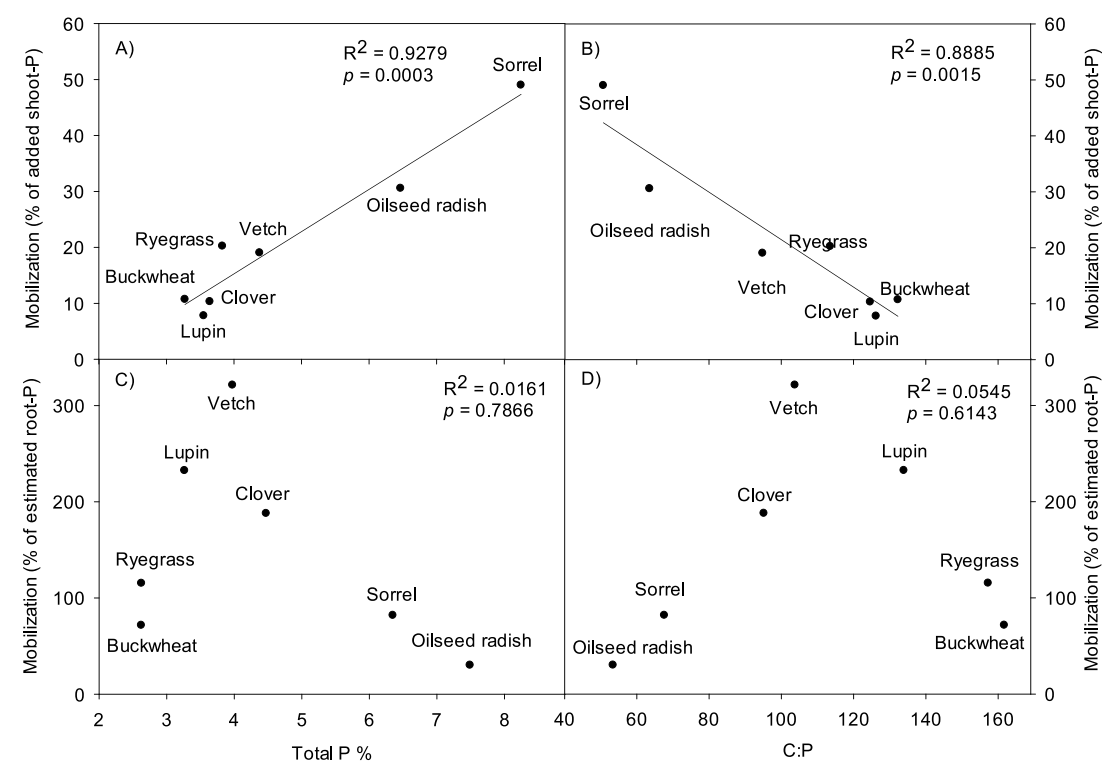

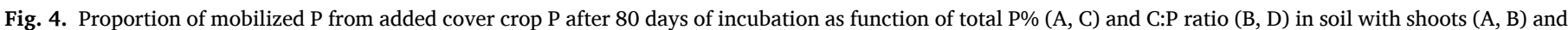
intact soil with roots (C, D).

become part of the non-soluble pool, and some of the increase in WEP may have been derived from changes in the solubility of soil P. However, since the soil had not been pre-labelled with a radioactive $\mathrm{P}$ tracer, it is not possible to account for differences in how residues may affect mobilization of soil P. One reason for the high and rapid P mobilization by sorrel could be the low tissue strength of the shoot material, which
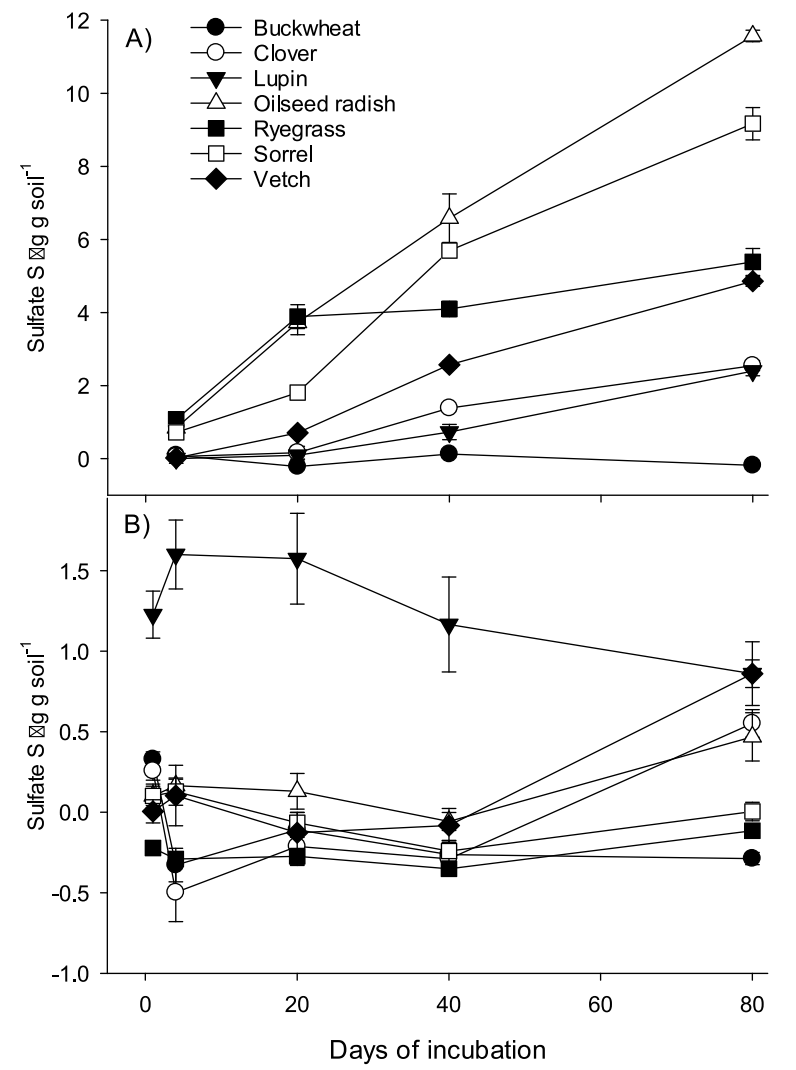

Fig. 5. Content of sulfate-S in cover crop treatments minus control soil during 80 days of incubation measured in: A) soil with shoots and B) intact soil with roots. Values presented here are means with standard error bars $(n=4$ for shoots, $\mathrm{n}=6$ for roots). allows fast disintegration and easier access for microbial degradation, as proposed in the study by Magid et al. (2004).

Although the $S$ mineralization rates were lower than in other studies, possibly due to the low temperature, the proportion of added $\mathrm{S}$ in shoot material was similar to previous studies and well predicted by the C:S ratio, with a C:S ratio below 200 resulting in net $S$ mineralization (Tabatabai and Chae, 1991; Eriksen and Thorup-Kristensen, 2002; Eriksen, 2005). Oilseed radish released the highest amount of sulfate, which is a well-known property of crucifers (Couëdel et al., 2018). However, sorrel released the highest proportion of added S (34\%), which has also been indicated in the study by Sorensen and Thorup-Kristensen (2011) where sorrel had a rather low S content, but the effect on cauliflower $S$ uptake was in the same range as that of crucifer cover crop rape (Brassica napus).

\subsection{Release of $N, P$ and $S$ from intact soil with roots of cover crops}

Generally, root material decomposes more slowly than aboveground material due to a lower $\mathrm{N}$ content and higher lignin content (De Neergaard et al., 2002). This was also the case in the current study. Furthermore, roots of legumes are less recalcitrant and decompose more quickly than the roots of non-legumes due to lower C:N ratios (De Neergaard et al., 2002) but also due to root anatomy and architecture, as suggested in a study by Lindedam et al. (2009), which found that clover roots are more open to microbial degradation than roots of fescue grass.

The root biomass recovered from $10 \mathrm{~cm}$ soil depth accounted for $10-50$ $\%$ of total harvested plant biomass. The $\mathrm{N}$ content of cover crop roots varied from $3.5-18.6 \mathrm{~kg} \mathrm{~N} \mathrm{ha}^{-1}$, which was lower than in the study by Li et al. (2015). The $\mathrm{N}$ concentration and C: $\mathrm{N}$ ratio of recoverable roots were good predictors of $\mathrm{N}$ mineralized in intact soil with roots. Legumes with a root C: $\mathrm{N}$ ratio below 20 released $\mathrm{N}$, whereas non-legumes with a $\mathrm{C}: \mathrm{N}$ ratio above 20 resulted in $\mathrm{N}$ immobilization, which is consistent with other studies (Lindedam et al., 2009). Lupin showed higher $\mathrm{N}$ mineralization during the first 40 days than the other legumes. However, the intact soil with vetch roots released $128 \%$ of estimated root $\mathrm{N}$, indicating release not only from recoverable roots but also from rhizodeposits and root-derived $\mathrm{N}$ not recovered (Kanders et al., 2017). Legumes leave more mineral $\mathrm{N}$ in the soil during their growing period than non-legumes (Thorup-Kristensen, 2006). Thus, the exclusion of $\mathrm{N}$ sources from soil around the roots underestimates the total amount of $\mathrm{N}$ stored by cover crops, especially for legumes (Fustec et al., 2009). 
Table 5

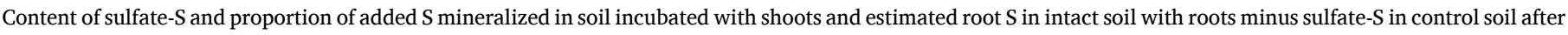

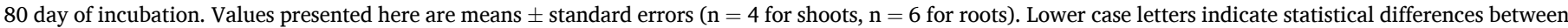
cover crop species $(\mathrm{p}<0.05)$.

\begin{tabular}{|c|c|c|c|c|}
\hline & \multicolumn{2}{|c|}{ Sulfate-S $\mu \mathrm{g} \mathrm{g} \mathrm{soil}^{-1}$} & \multirow{2}{*}{$\%$ of added shoot $\mathrm{S}$ mineralized } & \multirow{2}{*}{$\%$ of estimated root $\mathrm{S}$ mineralized } \\
\hline & Shoots & Intact soil with roots & & \\
\hline Buckwheat & $-0.2 \pm 0.1 \mathrm{e}$ & $-0.3 \pm 0.0 \mathrm{~b}$ & $-1.3 \pm 0.4 \mathrm{f}$ & $-3 \pm 0.4 c$ \\
\hline Clover & $2.6 \pm 0.1 \mathrm{~d}$ & $0.6 \pm 0.1 \mathrm{a}$ & $10.2 \pm 0.5 \mathrm{e}$ & $1.6 \pm 0.2 \mathrm{ab}$ \\
\hline Lupin & $2.4 \pm 0.1 \mathrm{~d}$ & $0.9 \pm 0.2 \mathrm{a}$ & $10.4 \pm 0.6 \mathrm{e}$ & $3 \pm 0.7 \mathrm{a}$ \\
\hline Oilseed radish & $11.6 \pm 0.2 \mathrm{a}$ & $0.5 \pm 0.2 \mathrm{a}$ & $28.2 \pm 0.4 \mathrm{~b}$ & $3.6 \pm 1.1 \mathrm{a}$ \\
\hline Ryegrass & $5.4 \pm 0.4 \mathrm{c}$ & $-0.1 \pm 0.0 \mathrm{~b}$ & $22.2 \pm 1.5 \mathrm{c}$ & $-0.2 \pm 0.0 \mathrm{~b}$ \\
\hline Sorrel & $9.2 \pm 0.4 \mathrm{~b}$ & $0.0 \pm 0.1 \mathrm{~b}$ & $34.3 \pm 1.7 \mathrm{a}$ & $0 \pm 0.4 \mathrm{~b}$ \\
\hline Vetch & $4.9 \pm 0.1 \mathrm{c}$ & $0.9 \pm 0.1 \mathrm{a}$ & $17.8 \pm 0.5 \mathrm{~d}$ & $1.5 \pm 0.1 \mathrm{ab}$ \\
\hline
\end{tabular}

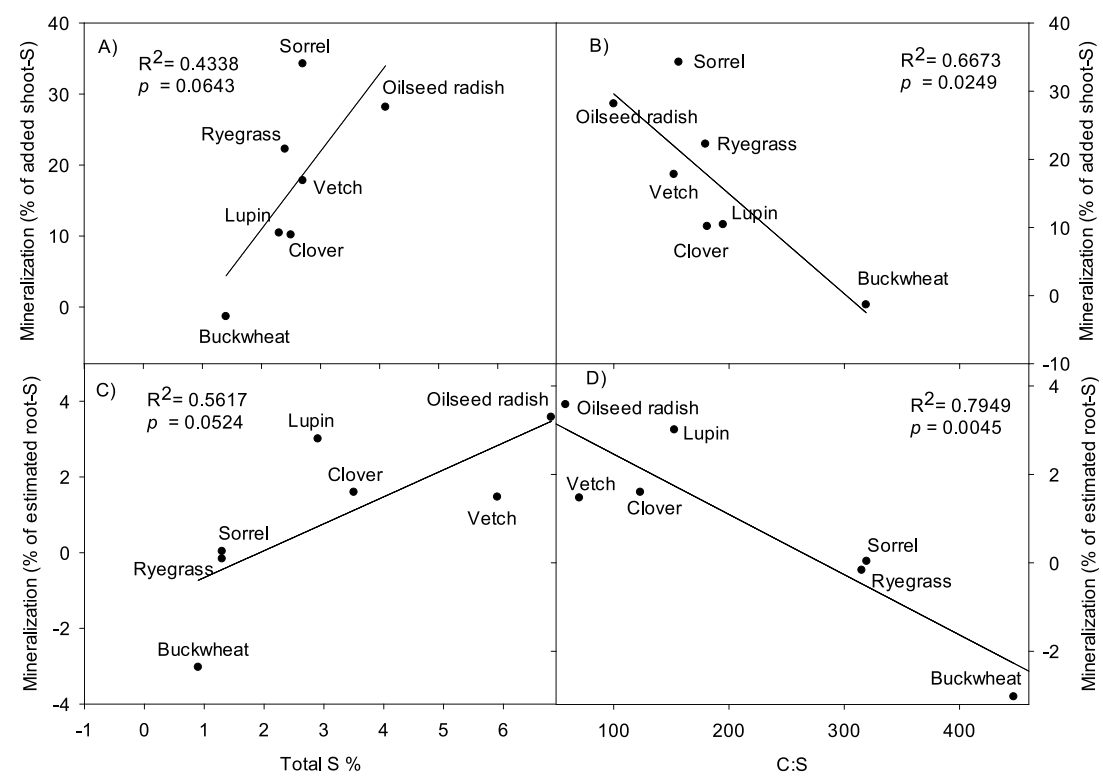

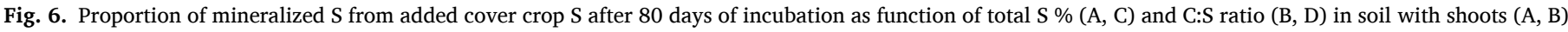
and intact soil with roots $(C, D)$.

Table 6

Estimated release potential of N, P and S from shoots and intact soil with roots in $10 \mathrm{~cm}$ depth based on the biomass production in the experimental field.

\begin{tabular}{|c|c|c|c|c|c|c|c|c|c|}
\hline & \multicolumn{3}{|c|}{$\mathrm{Kg}$ mineral $\mathrm{N} \mathrm{ha}^{-1}$} & \multicolumn{3}{|c|}{ Kg orthophosphate $-\mathrm{P}$ ha $^{-1}$} & \multicolumn{3}{|c|}{ Kg sulfate $-\mathrm{S} \mathrm{ha}^{-1}$} \\
\hline & Shoots & Intact soil with roots & Total & Shoots & Intact soil with roots & Total & Shoots & Intact soil with roots & Total \\
\hline Buckwheat & 11 & -2 & 10 & 1 & 1 & 2 & 0 & 0 & 0 \\
\hline Clover & 29 & 2 & 32 & 1 & 2 & 3 & 1 & 0 & 1 \\
\hline Lupin & 50 & 7 & 56 & 1 & 3 & 4 & 1 & 0 & 1 \\
\hline Oilseed radish & 22 & -3 & 19 & 4 & 2 & 6 & 2 & 0 & 3 \\
\hline Ryegrass & 32 & -3 & 29 & 2 & 3 & 5 & 1 & 0 & 1 \\
\hline Sorrel & 39 & -4 & 35 & 7 & 5 & 12 & 2 & 0 & 2 \\
\hline Vetch & 34 & 7 & 40 & 1 & 2 & 3 & 1 & 0 & 1 \\
\hline
\end{tabular}

Intact soil with clover, lupin, vetch and ryegrass roots released substantially more $\mathrm{P}$ than estimated root $\mathrm{P}$ (115-321 \%). This may indicate mobilization of $\mathrm{P}$ from the soil pool during the growth of the cover crops, since the content of WEP increased compared with the control soil and was almost constant throughout the incubation period for most species. In particular, soil with lupin roots showed a high initial WEP content. This may be due to lupin's ability to exude organic anions and phosphatases that enhance the availability of $\mathrm{P}$ in soil (Bayon et al., 2006). Furthermore, the roots of cover crop release rhizodeposits that shape the microbial community. Increased soil biological activity contributes to decomposition of cover crop residues and may increase the $\mathrm{P}$ availability for the subsequent crop (Hallama et al., 2019).
In intact soil with roots of the different species, the mineralization of $S$ was rather low ( $<4 \%$ of estimated root $S$ ), but the mineralization was clearly correlated with the C:S ratio. For oilseed radish and the three legumes (clover, lupin and vetch), the C:S ratios of root biomass were significantly lower than for shoot biomass, but concomitantly the lignin content was 2-5 times higher in root biomass, which may offer an explanation for the low mineralization rates. However, the mineralization of legume $S$ in shoot and root biomass seems complex. The C:S ratio of legumes is usually higher than that of crucifers (Eriksen et al., 2004), as shown in the current study. However, nitrogenase and ferredoxin in root nodules are exceptionally rich in S (Becana et al., 2018) and the S content of nodules of pea has been found to be 4-7 times higher than in 
Table 7

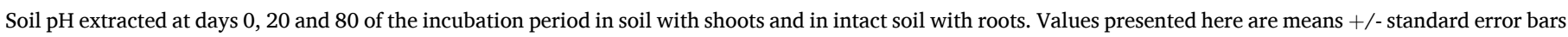

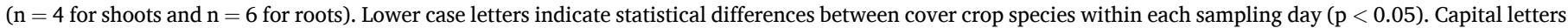
indicate statistical differences between sampling days within each cover crop specie, n.s. = not significant.

\begin{tabular}{|c|c|c|c|c|c|c|}
\hline Soil + shoots & Day 1 & & Day 20 & & Day 80 & \\
\hline Control & $6.49 \pm 0.01$ n.s. & N.S & $6.42 \pm 0.02 \mathrm{~d}$ & N.S. & $6.50 \pm 0.03 \mathrm{a}$ & N.S. \\
\hline Buckwheat & $6.49 \pm 0.01$ n.s. & A & $6.27 \pm 0.02 \mathrm{e}$ & B & $6.48 \pm 0.06 \mathrm{a}$ & A \\
\hline Clover & $6.49 \pm 0.01$ n.s. & B & $6.63 \pm 0.03 c$ & A & $5.77 \pm 0.04 c$ & $\mathrm{C}$ \\
\hline Lupin & $6.49 \pm 0.01$ n.s. & B & $6.79 \pm 0.03 \mathrm{a}$ & A & $5.72 \pm 0.02 c$ & $\mathrm{C}$ \\
\hline Oilseed radish & $6.49 \pm 0.01$ n.s. & B & $6.76 \pm 0.03 \mathrm{ab}$ & A & $6.26 \pm 0.02 \mathrm{~b}$ & C \\
\hline Ryegrass & $6.49 \pm 0.01$ n.s. & B & $6.58 \pm 0.01 \mathrm{c}$ & A & $5.73 \pm 0.02 c$ & $\mathrm{C}$ \\
\hline Sorrel & $6.49 \pm 0.01$ n.s. & B & $6.68 \pm 0.04 b c$ & A & $5.86 \pm 0.05 c$ & C \\
\hline Vetch & $6.49 \pm 0.01$ n.s. & B & $6.84 \pm 0.01 \mathrm{a}$ & A & $5.78 \pm 0.02 c$ & $\mathrm{C}$ \\
\hline \multicolumn{7}{|l|}{ Rooted soil } \\
\hline Control & $6.49 \pm 0.01 b c$ & N.S. & $6.49 \pm 0.01 \mathrm{c}$ & N.S. & $6.45 \pm 0.02 c$ & N.S. \\
\hline Buckwheat & $6.31 \pm 0.01 \mathrm{~d}$ & $\mathrm{C}$ & $6.45 \pm 0.01 c$ & B & $6.53 \pm 0.01 \mathrm{bc}$ & A \\
\hline Clover & $6.59 \pm 0.01 \mathrm{a}$ & $\mathrm{C}$ & $6.71 \pm 0.01 \mathrm{a}$ & B & $6.80 \pm 0.03 \mathrm{a}$ & A \\
\hline Lupin & $6.55 \pm 0.03 \mathrm{ab}$ & B & $6.66 \pm 0.03 \mathrm{ab}$ & $\mathrm{AB}$ & $6.77 \pm 0.04 \mathrm{a}$ & A \\
\hline Oilseed radish & $6.03 \pm 0.00 \mathrm{e}$ & $\mathrm{C}$ & $6.22 \pm 0.01 \mathrm{~d}$ & B & $6.34 \pm 0.01 \mathrm{~d}$ & A \\
\hline Ryegrass & $6.61 \pm 0.02 \mathrm{a}$ & B & $6.63 \pm 0.01 b$ & B & $6.72 \pm 0.01 \mathrm{a}$ & A \\
\hline Sorrel & $6.44 \pm 0.02 c$ & $\mathrm{C}$ & $6.61 \pm 0.01 \mathrm{~b}$ & B & $6.72 \pm 0.02 \mathrm{a}$ & A \\
\hline Vetch & $6.60 \pm 0.01 \mathrm{a}$ & N.S. & $6.62 \pm 0.02 b$ & N.S. & $6.60 \pm 0.04 b$ & N.S. \\
\hline
\end{tabular}

shoots (Scherer et al., 2006). Based on this, the S mineralization from intact soil with legume roots could be expected to be higher than predicted from isolated root material, where full recovery of nodules may be very difficult to achieve. Nevertheless, in the present study mineralization from soil with roots was only a few percentage points of the estimated root $\mathrm{S}$ content. The mechanisms for root and soil contribution to the S supply of subsequent crops are still not fully understood.

\subsection{Potential for multifunctional cover crop mixtures}

There is increasing interest in growing multifunctional cover crops and cover crop mixtures providing green manure services within cropping systems (Sorensen and Thorup-Kristensen, 2011; Tribouillois et al., 2016; Couëdel et al., 2018). Multifunctional cover crop mixtures with complementary plant functional traits may supply different nutrients to the subsequent crop (Sorensen and Thorup-Kristensen, 2011; Couëdel et al., 2018). Therefore, in a multifunctional mixture, different plant functional groups should be represented, e.g. legumes, crucifers and winter-persistent monocots. In the present study, sorrel released the highest proportion of added N, P and S, and therefore has the potential to become an undersown cover crop providing multiple nutrients. Due to their high $\mathrm{P}$ concentration and $\mathrm{P}$ release, sorrel and oilseed radish have the potential to enhance $P$ nutrition of succeeding crops. These two species also had the highest $\mathrm{K}$ concentration and sorrel had the highest $\mathrm{Mg}$ concentration. Lupin accumulated high amounts of Mn in the shoot biomass, which has also been shown in other studies and has been attributed to the release of carboxylates into the rhizosphere and increasing the availability not only of $\mathrm{P}$, but of $\mathrm{Mn}$ as well (Lambers et al., 2015). As lupin reached a high biomass production, it may be viewed as a cover crop that increases N, P and Mn availability in the soil. In the study by Zhu et al. (2002), buckwheat was shown to be efficient in taking up Ca-bound P by acidifying the rhizosphere. In the present study, buckwheat achieved the highest biomass, lignin content and consequently lowest release rates of N, P and S, and is therefore not considered a $\mathrm{P}$ efficient cover crop. Vetch had the highest $\mathrm{N}$ concentration and reached the highest $\mathrm{N}$ mineralization rate, and as a winter-persistent legume, it has the potential to accumulate and release high amounts of $\mathrm{N}$ for the subsequent crop, resulting in positive yield effects (Thorup-Kristensen et al., 2003; Büchi et al., 2015). A substantial release of nutrients and supply to the subsequent crop depends not only on the concentration of nutrients in cover crops and the release rate, but also on the biomass amount produced in the field (Wendling et al., 2016). Based on the estimates in the present study, lupin would release the most $\mathrm{N}$, sorrel the most $\mathrm{P}$ and oilseed radish the most $\mathrm{S}$. Although, lab-incubation data cannot be directly converted to field-scale results, the magnitude of these maximum release rates corresponds to approximately $56 \mathrm{~kg} \mathrm{~N}$ $\mathrm{ha}^{-1}$ (lupin), $12 \mathrm{~kg} \mathrm{P} \mathrm{ha}^{-1}$ (sorrel) and $3 \mathrm{~kg} \mathrm{~S}^{-1}$ (oilseed radish). Under field conditions, these rates may vary though, due to variable temperatures, freezing and thawing, tillage and the impact of heterogeneity found in the field. The focus of our study was the nutrient release potential after incorporation of cover crops in top soil. Our estimates of nutrient release potential in the field were therefore based on excavated soil in $10 \mathrm{~cm}$ depth, where the highest root biomass is often observed (Frasier et al., 2016). However, this potential could be underestimated for some species, as root systems vary greatly among cover crop species (Wendling et al., 2016) and can reach depth of $2.5 \mathrm{~m}$ (Thorup-Kristensen and Rasmussen, 2015). The potential for $\mathrm{P}$ release is quite high compared with the subsequent crop demand considering the moderately low fertility in the field used in the present study (see section 2.1). If the nutrient release is well synchronized in time and place with the demand of a subsequent crop, these released amounts may represent a substantial nutrient supply, especially in the case of $\mathrm{N}$ and P. Furthermore, the synchronization in time and place is also crucial to avoid nutrient leaching, especially regarding $\mathrm{N}$. This synchronization is even more important in areas with sandy soils and high winter precipitation compared to the location of the current field trial, where the risk of $\mathrm{N}$ leaching is lower (Askegaard et al., 2005). Nevertheless, it is important to bear in mind that winter-persistent species such as hairy vetch and Italian ryegrass and semi-persistent species such as crimson clover and oilseed radish would continue to grow during the winter, whereas lupin and buckwheat can be terminated by frost in early November. The winter-persistent species may therefore take up even more nutrients, but also alter their chemical composition towards a higher C-to-nutrient ratio (Thorup-Kristensen and Dresb $ø 11,2010)$. Furthermore, designing of cover crop mixtures can increase their multifunctionality compared with single species, e.g. a supply of different nutrients, although these effects are not always additive, and trade-offs between functions may occur (Blesh, 2018). Thus, less growth of each species in a cover crop mixture will reduce its uptake and contribution compared with a single cover crop.

\section{Conclusions}

This study has demonstrated the importance of unrecoverable pools, such as rhizodeposits and nodules, in contributing to $\mathrm{N}$ release and $\mathrm{P}$ mobilization. The $\mathrm{N}$ release from shoots was non-stoichiometrical at the low temperature applied, which is relevant for cool temperate agroecosystems. The results indicate a considerable difference between 
plant species in their uptake and release of N, P and S and other nutrients, such as $\mathrm{K}, \mathrm{Mg}$ and $\mathrm{Mn}$. These traits are promising for future ecological intensification of organic farming systems. However, more knowledge on interactions between species when grown together is needed in order to design efficient multifunctional cover crop mixtures.

\section{Funding}

This research was part of the project NutHY (Nutrients for higher organic crop yields), financially supported by the Green Development and Demonstration Programme (grant number 34009-16-1133) and coordinated by the International Centre for Research in Organic Food systems (ICROFS).

\section{Declaration of Competing Interest}

The authors report no declarations of interest.

\section{Acknowledgments}

We would like to thank Lena Asta Byrgesen and Jannie Margrethe Jessen for her help with laboratory work and Ulrich Bay Olsen for his assistance at the experimental farm in Taastrup.

\section{References}

Andersen, M.K., Jensen, L.S., 2001. Low soil temperature effects on short-term gross N mineralisation-immobilisation turnover after incorporation of a green manure. Soil Biol. Biochem. https://doi.org/10.1016/S0038-0717(00)00192-9.

Arcand, M.M., Knight, J.D., Farrell, R.E., 2013. Temporal dynamics of nitrogen rhizodeposition in field pea as determined by $15 \mathrm{~N}$ labeling. Can. J. Plant Sci. 93, 941-950. https://doi.org/10.4141/CJPS2013-050.

Askegaard, M., Olesen, J.E., Kristensen, K., 2005. Nitrate leaching from organic arable crop rotations: effects of location, manure and catch crop. Soil Use Manage. 21, 181-188. https://doi.org/10.1079/sum2005315.

Bayon, R.C.L., Weisskopf, L., Martinoia, E., Jansa, J., Frossard, E., Keller, F., Föllmi, K.B., Gobat, J.M., 2006. Soil phosphorus uptake by continuously cropped Lupinus albus: a new microcosm design. Plant Soil 283, 309-321. https://doi.org/10.1007/s11104006-0021-4.

Becana, M., Wienkoop, S., Matamoros, M.A., 2018. Sulfur transport and metabolism in legume root nodules. Front. Plant Sci. 9, 1-10. https://doi.org/10.3389/ fpls.2018.01434.

Blanco-Canqui, H., Shaver, T.M., Lindquist, J.L., Shapiro, C.A., Elmore, R.W., Francis, C. A., Hergert, G.W., 2015. Cover crops and ecosystem services: insights from studies in temperate soils. Agron. J. 107, 2449-2474. https://doi.org/10.2134/agronj15.0086.

Blesh, J., 2018. Functional traits in cover crop mixtures: biological nitrogen fixation and multifunctionality. J. Appl. Ecol. 55, 38-48. https://doi.org/10.1111/13652664.13011.

Breland, T.A., 1994. Measured and predicted mineralization of clover green manure at low-temperatures at different depths in 2 soils. Plant Soil 166, 13-20.

Büchi, L., Gebhard, C.A., Liebisch, F., Sinaj, S., Ramseier, H., Charles, R., 2015. Accumulation of biologically fixed nitrogen by legumes cultivated as cover crops in Switzerland. Plant Soil 393, 163-175. https://doi.org/10.1007/s11104-015-2476-7.

Cooper, J., Reed, E.Y., Hörtenhuber, S., Lindenthal, T., Løes, A.K., Mäder, P., Magid, J., Oberson, A., Kolbe, H., Möller, K., 2018. Phosphorus availability on many organically managed farms in Europe. Nutr. Cycl. Agroecosyst. 110, 227-239. https://doi.org/10.1007/s10705-017-9894-2.

Couëdel, A., Alletto, L., Justes, É, 2018. Crucifer-legume cover crop mixtures provide effective sulphate catch crop and sulphur green manure services. Plant Soil 426 , 61-76. https://doi.org/10.1007/s11104-018-3615-8.

Damon, P.M., Bowden, B., Rose, T., Rengel, Z., 2014. Crop residue contributions to phosphorus pools in agricultural soils: a review. Soil Biol. Biochem. 74, 127-137. https://doi.org/10.1016/j.soilbio.2014.03.003.

De Baets, S., Poesen, J., Meersmans, J., Serlet, L., 2011. Cover crops and their erosionreducing effects during concentrated flow erosion. Catena 85, 237-244. https://doi. org/10.1016/j.catena.2011.01.009.

De Neergaard, A., Hauggaard-Nielsen, H., Stoumann Jensen, L., Magid, J., 2002. Decomposition of White clover (Trifolium repens) and Ryegrass (Lolium perenne) components: $\mathrm{C}$ and $\mathrm{N}$ dynamics simulated with the DAISY soil organic matter submodel. Eur. J. Agron. 16, 43-55. https://doi.org/10.1016/S1161-0301(01) 00118-6.

Eriksen, J., 2005. Gross sulphur mineralisation-immobilisation turnover in soil amended with plant residues. Soil Biol. Biochem. 37, 2216-2224. https://doi.org/10.1016/j. soilbio.2005.04.003.

Eriksen, J., 2009. Soil sulfur cycling in temperate agricultural systems. Adv. Agron. 102, 55-89. https://doi.org/10.1016/S0065-2113(09)01002-5.
Eriksen, J., Thorup-Kristensen, K., 2002. The effect of catch crops on sulphate leaching and availability of $S$ in the succeeding crop on sandy loam soil in Denmark. Agric. Ecosyst. Environ. 90, 247-254. https://doi.org/10.1016/S0167-8809(01)00214-6.

Eriksen, J., Thorup-Kristensen, K., Askegaard, M., 2004. Plant availability of catch crop sulfur following spring incorporation. J. Plant Nutr. Soil Sci. 167, 609-615. https:// doi.org/10.1002/jpln.200420415.

Frasier, I., Noellemeyer, E., Fernández, R., Quiroga, A., 2016. Direct field method for root biomass quantification in agroecosystems. MethodsX 3, 513-519. https://doi.org/ 10.1016/j.mex.2016.08.002.

Fustec, J., Lesuffleur, F., Mahieu, S., Cliquet, J.B., 2009. Nitrogen rhizodeposition of legumes. Sustain. Agric. 2, 869-881. https://doi.org/10.1007/978-94-007-0394-0 38.

Hallama, M., Pekrun, C., Lambers, H., Kandeler, E., 2019. Hidden miners - the roles of cover crops and soil microorganisms in phosphorus cycling through agroecosystems. Plant Soil 434, 7-45. https://doi.org/10.1007/s11104-018-3810-7.

Hinsinger, P., Betencourt, E., Bernard, L., Brauman, A., Plassard, C., Shen, J., Tang, X., Zhang, F., 2011. P for two, sharing a scarce resource: soil phosphorus acquisition in the rhizosphere of intercropped species. Plant Physiol. 156, 1078-1086. https://doi. org $/ 10.1104 / \mathrm{pp} .111 .175331$.

Jensen, L.S., Salo, T., Palmason, F., Breland, T.A., Henriksen, T.M., Stenberg, B, Pedersen, A., Lundström, C., Esala, M., 2005. Influence of biochemical quality on C and $\mathrm{N}$ mineralisation from a broad variety of plant materials in soil. Plant Soil 273, 307-326. https://doi.org/10.1007/s11104-004-8128-y.

Kanders, M.J., Berendonk, C., Fritz, C., Watson, C., Wichern, F., 2017. Catch crops store more nitrogen below-ground when considering Rhizodeposits. Plant Soil 417, 287-299. https://doi.org/10.1007/s11104-017-3259-0.

Lambers, H., Hayes, P.E., Laliberté, E., Oliveira, R.S., Turner, B.L., 2015. Leaf manganese accumulation and phosphorus-acquisition efficiency. Trends Plant Sci. 20, 83-90. https://doi.org/10.1016/j.tplants.2014.10.007.

Li, X., Petersen, S.O., Sørensen, P., Olesen, J.E., 2015. Effects of contrasting catch crops on nitrogen availability and nitrous oxide emissions in an organic cropping system. Agric. Ecosyst. Environ. 199, 382-393. https://doi.org/10.1016/j. agee. 2014.10.016.

Li, F., Sørensen, P., Li, X., Olesen, J.E., 2020. Carbon and nitrogen mineralization differ between incorporated shoots and roots of legume versus non-legume based cover crops. Plant Soil 446, 243-257. https://doi.org/10.1007/s11104-019-04358-6.

Lindedam, J., Magid, J., Poulsen, P., Luxhøi, J., 2009. Tissue architecture and soil fertility controls on decomposer communities and decomposition of roots. Soil Biol. Biochem. 41, 1040-1049. https://doi.org/10.1016/j.soilbio.2009.01.023.

Liu, J., Khalaf, R., Ulén, B., Bergkvist, G., 2013. Potential phosphorus release from catch crop shoots and roots after freezing-thawing. Plant Soil 371, 543-557. https://doi. org/10.1007/s11104-013-1716-y.

Magid, J., Henriksen, O., Thorup-Kristensen, K., Mueller, T., 2001. Disproportionately high $\mathrm{N}$-mineralisation rates from green manures at low temperatures - implications for modeling and management in cool temperate agro-ecosystems. Plant Soil. https://doi.org/10.1023/a:1004860329146.

Magid, J., Luxhøi, J., Lyshede, O.B., 2004. Decomposition of plant residues at low temperatures separates turnover of nitrogen and energy rich tissue components in time. Plant Soil 258, 351-365. https://doi.org/10.1023/B: PLSO.0000016565.14718.4b.

McGill, W.B., Cole, C.V., 1981. Comparative aspects of cycling of organic C, N, S and P trough soil organic matter. Geoderma 26, 267-286.

Muller, M.M., Sundman, V., 1988. The fate of nitrogen (N-15) released from different plant materials during decomposition under field conditions. Plant Soil 105, 133-139.

Poeplau, C., Don, A., 2015. Carbon sequestration in agricultural soils via cultivation of cover crops - a meta-analysis. Agric. Ecosyst. Environ. 200, 33-41. https://doi.org/ 10.1016/j.agee.2014.10.024.

R Core Team, 2017. R: A Language and Environment for Statistical Computing. R Foundation for Statistical Computing, Vienna, Austria.

RStudio Team, 2017. RStudio: Integreated Development for R. RStudio, Inc., Boston, MA.

Scherer, H.W., Pacyna, S., Manthey, N., Schulz, M., 2006. Sulphur supply to peas (Pisum sativum L.) influences symbiotic N 2 fixation. Plant Soil Environ. 52, 72-77. https:// doi.org/10.17221/3348-pse.

Seufert, V., Ramankutty, N., Foley, J.A., 2012. Comparing the yields of organic and conventional agriculture. Nature 485, 229-232. https://doi.org/10.1038/ nature11069.

Shah, A., Askegaard, M., Rasmussen, I.A., Jimenez, E.M.C., Olesen, J.E., 2017. Productivity of organic and conventional arable cropping systems in long-term experiments in Denmark. Eur. J. Agron. 90, 12-22. https://doi.org/10.1016/j. eja.2017.07.001.

Sorensen, J.N., Thorup-Kristensen, K., 2011. Plant-based fertilizers for organic vegetable production. J. Plant Nutr. Soil Sci. 174, 321-332. https://doi.org/10.1002/ jpln.200900321.

Tabatabai, M., Chae, Y., 1991. Mineralization of sulfur in soils amended with organic wastes. J. Environ. Qual. 20, 684-690.

Thomsen, I.K., Elsgaard, L., Olesen, J.E., Christensen, B.T., 2016. Nitrogen release from differently aged Raphanus sativus L. nitrate catch crops during mineralization at autumn temperatures. Soil Use Manage. 32, 183-191. https://doi.org/10.1111/ sum.12264.

Thorup-Kristensen, K., 2006. Root growth and nitrogen uptake of carrot, early cabbage, onion and lettuce following a range of green manures. Soil Use Manage. 22, 29-38. https://doi.org/10.1111/j.1475-2743.2005.00012.x.

Thorup-Kristensen, K., Dresbøll, D.B., 2010. Incorporation time of nitrogen catch crops influences the $\mathrm{N}$ effect for the succeeding crop. Soil Use Manage. 26, 27-35. https:// doi.org/10.1111/j.1475-2743.2009.00255.x. 
Thorup-Kristensen, K., Rasmussen, C.R., 2015. Identifying new deep-rooted plant species suitable as undersown nitrogen catch crops. J. Soil Water Conserv. 70, 399-409. https://doi.org/10.2489/jswc.70.6.399.

Thorup-Kristensen, K., Magid, J., Jensen, L.S., 2003. Catch crops and green manures as biological tools in nitrogen management in temperate zones. Adv. Agron. 79, 227-302. https://doi.org/10.1016/S0065-2113(02)79005-6.

Tribouillois, H., Cohan, J.P., Justes, E., 2016. Cover crop mixtures including legume produce ecosystem services of nitrate capture and green manuring: assessment combining experimentation and modelling. Plant Soil 401, 347-364. https://doi. org/10.1007/s11104-015-2734-8. van der Paauw, F., 1971. An effective water extraction method for the determination of plant-available soil phosphorus. Plant Soil 34, 467-481. https://doi.org/10.1007/ BF01372799.

Van Soest, P.J., Robertson, J.B., Lewis, B.A., 1991. Methods for dietary fiber, neutral detergent fiber, and nonstarch polysaccharides in relation to animal nutrition. J. Dairy Sci. 74, 3583-3597. https://doi.org/10.3168/jds.S0022-0302(91)78551-2.

Wendling, M., Büchi, L., Amossé, C., Sinaj, S., Walter, A., Charles, R., 2016. Influence of root and leaf traits on the uptake of nutrients in cover crops. Plant Soil 409, 419-434. https://doi.org/10.1007/s11104-016-2974-2.

Zhu, Y.G., He, Y.Q., Smith, S.E., Smith, F.A., 2002. Buckwheat (Fagopyrum esculentum Moench) has high capacity to take up phosphorus (P) from a calcium (Ca)-bound source. Plant Soil 239, 1-8. https://doi.org/10.1023/A:1014958029905. 